\title{
Procentage of E-commerce Utilization among UIN Maulana Malik Ibrahim Malang Students
}

\author{
Ahmad Rizkyka Agung Hidhayat ${ }^{a, 1, *}$, Setya Yudistira ${ }^{a, 2}$, Felix Andika Dwiyanto ${ }^{b, 3}$ \\ ${ }^{a}$ Universitas Islam Negeri Maulana Malik Ibrahim, Malang, Indonesia \\ ${ }^{\mathrm{b}}$ Association for Scientific Computing Electrical and Engineering, Yogyakarta, Indonesia \\ ${ }^{1}$ ahmadrizkyka@ gmail.com; ${ }^{2}$ raditzrastogi@gmail.com; ${ }^{3}$ ayikgugun@ gmail.com
}

\begin{tabular}{|c|c|}
\hline Article Info & " ABSTRACT \\
\hline $\begin{array}{l}\text { Article history: } \\
\text { Received: September 4, } 2019 \\
\text { Revised: September 20, } 2019 \\
\text { Accepted: October 7, } 2019\end{array}$ & $\begin{array}{l}\text { This study aims to discover the influence of e-commerce on student life, both in terms of } \\
\text { understanding and its use. The variables analyzed include the level of understanding, } \\
\text { the experience of a transaction through e-commerce, reasons for choosing e-commerce, } \\
\text { e-commerce knowledge sources, and a list of e-commerce sites they have used. } \\
\text { Respondents were students of the State Islamic University of Maulana Malik Ibrahim } \\
\text { Malang. A simple random sampling technique used in this study. As for the data } \\
\text { collection, using a questionnaire technique. The obtained data will be processed and } \\
\text { analyzed. Generally, the results of the study explain that most students know e- } \\
\text { commerce, but the use is still not optimal, even very less. }\end{array}$ \\
\hline
\end{tabular}

Students

Diagram

\section{INTRODUCTION}

The development of the internet led to the formation of a new world which is commonly called the virtual world. In this virtual world, every individual has the right and ability to interact with other individuals without any restrictions that can prevent him [1], [2]. So that perfect globalization has been running in cyberspace which connects the entire digital community. From all aspects of human life affected by the presence of the internet, the business sector is the sector most affected by the development of information technology and telecommunications and the fastest growing [3]. Through ecommerce, for the first time, all people on earth have the same opportunities to compete and succeed in doing business in cyberspace [4].

E-commerce is a type of electronic business mechanism that focuses on individual-based business transactions using the internet (digital network-based technology) as a medium for exchanging goods or services between two institutions (business to business) and direct consumers (business to consumer), bypassing space and dominant time constraints [4], [5]. In times of fierce competition in the current era of globalization, the real competition lies in how a company can utilize e-commerce to improve performance and existence in the core business [6]. With e-commerce applications, the relationship between companies and other external entities (suppliers, distributors, partners, customers) can be done faster, more intensively, and cheaper than the conventional application of management principles. So e-commerce is not just a mechanism for selling goods or services through the internet medium, but also to the occurrence of a business transformation that changes the way companies look at doing business activities. Building and implementing an e-commerce system is not an instant process but is a transformation of strategies and business systems that continue to grow in line with the development of the company and technology.

\section{THEORETICAL BASIS}

E-Commerce is a process of buying and selling products electronically by consumers and from company to company with computers as intermediaries for business transactions [5]. E-Commerce or commonly referred to as Ecom, Emmerce, or $\mathrm{EC}$ is a routine business exchange using Electronic Data Interchange (EDI) transmissions, e-mails, electronic bulletin boards, facsimile machines, and Electronic Funds Transfers relating to shopping transactions on Internet shopping, online stocks and bonds, downloading and selling software, documents, graphics, music, etc., as well as Business to Business (B2B) transactions [7]. E-Commerce is a dynamic set of technologies, applications, and business processes that link 
enterprises, consumers, and communities through electronic transactions and the electronic exchange of goods, services, and information. E-Commerce is a dynamic set of technologies, applications, and business processes that connect certain companies, consumers and communities through electronic transactions and the trading of goods, services and information conducted electronically.

\section{A. A Brief History of E-Commerce Development}

The emergence of E-commerce was first introduced in 1994 when the first electronic-banner was used for promotional and advertising purposes on a web page. According to Forrester Research, electronic commerce resulted in sales of US 12.2 billion in 2003. According to another report in October 2006, online non-travel retail revenue in the United States is forecast to reach a quarter of a trillion US dollars in 2011.

\section{B. Types of E-Commerce}

E-Commerce activities include many things, to distinguish it can be divided into 2 based on its characteristics [8], [9]:

- Business to Business, its characteristics are (1) Trading partners who already know each other and between them have established a longstanding relationship. (2) Data exchange is carried out repeatedly and periodically in a mutually agreed upon data format. (3) One of the perpetrators does not have to wait for their other colleagues to send data. (4) The commonly used model is peer to peer, where processing intelligence can be distributed to both business people.

- Business to Consumer, its characteristics are (1) Open to the public, where information is disseminated publicly as well. (2) The services used are also general in nature, so they can be used by many people. (3) Services used on request. (4) A client-server approach is often used.

\section{E-Commerce Advantages}

There are some advantages of E-commerce such as [10]: (1) Do not recognize any place restrictions because transactions can occur even though consumers and sellers are in different places. (2) Make time efficient because you don't know the limits or every e-commerce transaction can be done for 24 hours. (3) Fewer employees are needed to make transactions so as to erode the seller's expenditure budget.

\section{E-Commerce Weakness}

There are also weakness of e-commerce implementation, such as [10]: (1) Frequent frauds such as fictitious credit cards, or sometimes seller fraud against customers because the laws governing e-commerce are still not very developed. (2) Consumers can not directly see the condition of the goods to be purchased. (3) Narrowing employment because the ecommerce industry does not require many employees to service transactions.

\section{METHOD}

The population in this study is students of UIN Maulana Malik Ibrahim Malang. It is not all of students are examined as research objects. To get the sample used a random sampling technique. A random sampling is drawn from a population and each member of the population has the same opportunity to be chosen as a sample.

In this study the method used to obtain information from respondents is in the form of a questionnaire. This type of questionnaire is a closed questionnaire with a Likert scale. The closed questionnaire answers that have been provided so that the respondent is left to choose the column that has been provided in the column by giving a cross $(\mathrm{X})$. The reason that a closed questionnaire selection is because the method provides convenience to the staff in providing answers, it is more practical and systematic.

\section{RESULT AND DISCUSSION}

Understand Do not understand

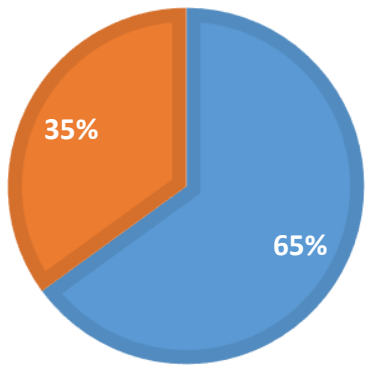

Fig. 1. E-commerce understanding level

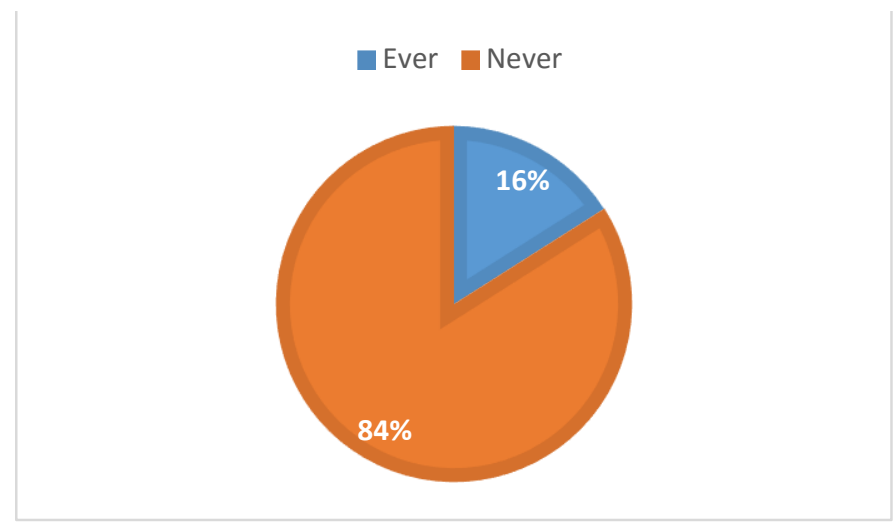

Fig. 2. Buying a stuff through e-commerce

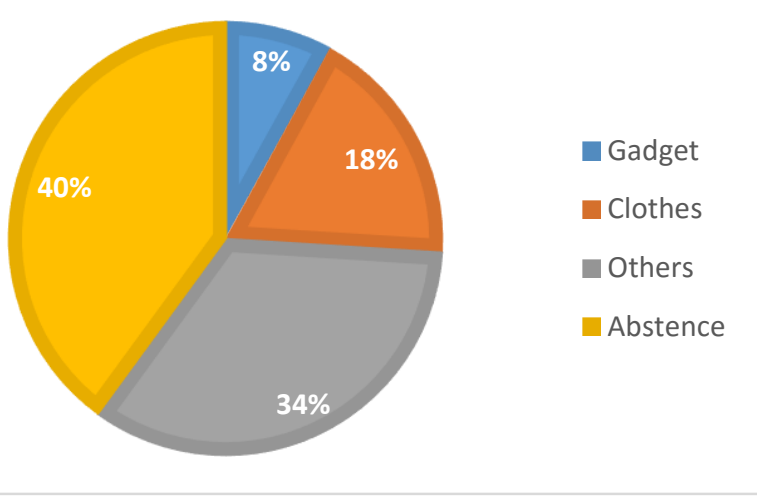

Fig. 3. Purchased stuff 


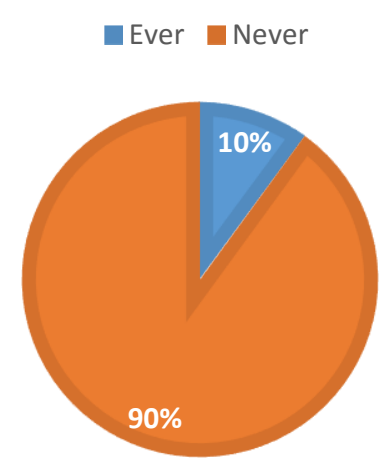

Fig. 4. Selling a stuff through e-commerce

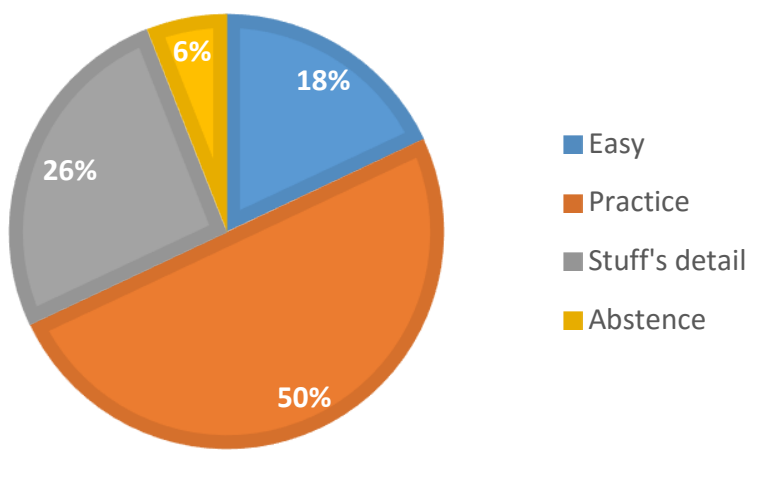

Fig. 5. Reason to choose e-commerce

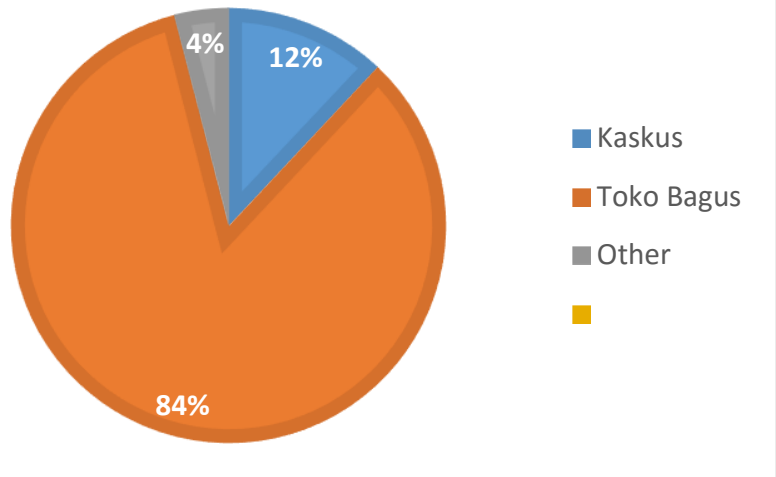

Fig. 6. Common used sites

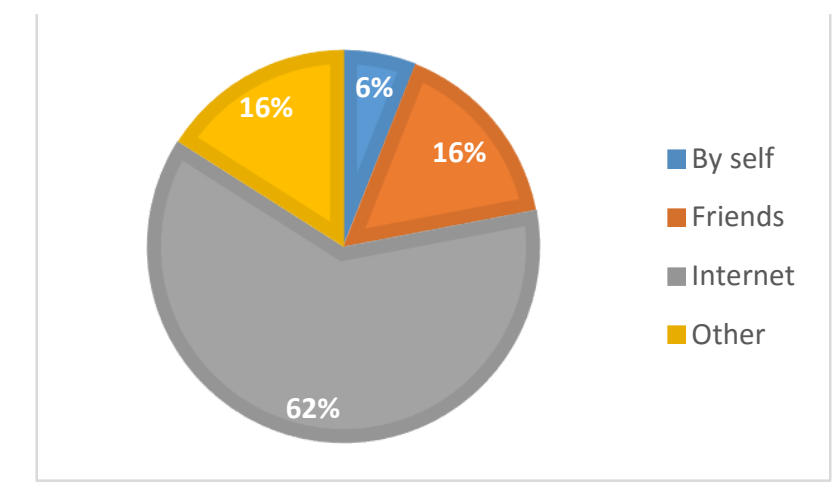

Fig. 7. Knowledge resources about e-commerce
Based on the Figure 1 to 7 , it can be analyzed that many of students know about E-Commerce both from the internet and from their friends, but still lacking in the application of ECommerce itself. Some of those who have used E-Commerce have bought goods online. For example gadgets, clothing and many others. But in the case of selling goods most of them have never used E-Commerce.

\section{CONCLUSION}

E-Commerce is a process of buying and selling products electronically by consumers and from company to company with computers as intermediaries for business transactions. There are two types of E-Commerce based on their characteristics, Business to Business and Business to Consumer. One of the advantages of E-Commerce is that there are no place restrictions because transactions can occur even if consumers and sellers are in different places. And one of the weaknesses of E-Commerce is that consumers cannot see directly the condition of the goods to be purchased.

\section{References}

[1] W. J. McIver Jr and W. F. Birdsall, "Technological evolution and the right to communicate," in Euricomm Colloquium: Electronic Networks and Democracy, 2002, pp. 9-12.

[2] W. McIver, W. Birdsall, and M. Rasmussen, "The Internet and the right to communicate," First Monday, vol. 8, no. 12, 2003.

[3] P. S. Aithal, "Concept of Ideal Business \& Its Realization Using EBusiness Model,” Int. J. Sci. Res., vol. 4, no. 3, pp. 1267-1274, 2015.

[4] Y. Yu, X. Wang, R. Y. Zhong, and G. Q. Huang, "E-commerce logistics in supply chain management: Practice perspective," Procedia Cirp, vol. 52, pp. 179-185, 2016.

[5] S. L. A. I. Linda, "Social commerce-e-commerce in social media context," World Acad. Sci. Eng. Technol., vol. 72, pp. 39-44, 2010.

[6] D. K. Gangeshwer, "E-commerce or Internet Marketing: A business Review from Indian context," Int. J. u-and e-Service, Sci. Technol., vol. 6, no. 6, pp. 187-194, 2013.

[7] A. Gupta, "E-Commerce: Role of E-Commerce in today's business," Int. J. Comput. Corp. Res., vol. 4, no. 1, pp. 1-8, 2014.

[8] Y. Tian and C. Stewart, "History of e-commerce," in Encyclopedia of ecommerce, e-government, and mobile commerce, 2006, pp. 559-564.

[9] R. Mangiaracina, G. Marchet, S. Perotti, and A. Tumino, "A review of the environmental implications of B2C e-commerce: a logistics perspective," Int. J. Phys. Distrib. Logist. Manag., vol. 45, no. 6, pp. 565-591, 2015.

[10] M. Niranjanamurthy, N. Kavyashree, S. Jagannath, and D. Chahar, "Analysis of e-commerce and m-commerce: advantages, limitations and security issues," Int. J. Adv. Res. Comput. Commun. Eng., vol. 2, no. 6, pp. 2360-2370, 2013. 